\title{
An Integrated Framework for the Development of Green Infrastructure: A Literature Review
}

by

\author{
P. Beauchamp ${ }^{1}$ and J. Adamowski ${ }^{2}$
}

\begin{abstract}
Green infrastructure (GI) has emerged as an active term of reference in project development planning. A gap exists in the GI research literature in the form of the absence of an integrated framework to assist engineering organizations in planning the start-up of new projects in the context of greening and sustainability. This study attempts to identify the existing frameworks that propose the development of green projects.

The first purpose of this study is to explore the use of fully integrated GI in the engineering design of a modern, new development. A clear sequence of tasks must define the workflow, leading teamwork. This literature review identifies several different approaches and selects four to build a ready-to-use framework of sequenced tasks, which includes all the components of water management (rain and drainage, water supply and wastewater).

This essay reviews GI literature with a focus on water resources and ecosystem services. It includes the methods, tools, and techniques available in different approaches, such as low impact development (LID), leadership in energy and environmental design (LEED), the British Columbia (BC) guidebook, and the EPA (Environmental Protection Agency) scorecard. It explores different frameworks to start or structure an urban development project.
\end{abstract}

Key Words: Green Infrastructure, climate change, environment

\section{Introduction}

While architects and designers are beginning to incorporate biophilia into their work, planners and policymakers who consider cities lag behind; the subject raises serious questions about what a city is or could be, and what constitutes a livable, sustainable environment (Beatly, 2010). Authors like Sim Van Der Ryn promote the concept of ecological design. Perhaps the most compelling theme of ecological design is

${ }^{1}$ P.Eng. Sen. VP International, exp. Services Inc.

2 Ph.D. Prof. Department of Bioresource Engineering, McGill University 
the search for a unified approach to the design of sustainable systems that integrates scales ranging from molecular to global (Van Der Ryn \& Cowen, 2007). Many authors propose green infrastructure (GI) as a way to design sustainable city systems. As a generic concept, GI also includes water.

The last ten years have seen extraordinary theoretical and technical advances in the field of ecological design; yet the challenges facing the planet have accelerated, ranging from the loss of biodiversity to rapidly increasing effects of global climate change (Van Der Ryn \& Cowen, 2007). Stormwater management is an increasing concern due to climate change and water supply in terms of quality and quantity is also significant. Contamination of water sources is another concern resulting from pollution. These elements can be addressed differently in designing new green developments. The philosophy of integrated water resource management is a concern and must be linked to greening the city. Facing uncertainty, adaptive management (AM) is a suitable approach to define GI.

The concept of AM has been designed primarily to support managers in dealing with highly connected systems (Wietske \& Jeffrey, 2005). The development of new metrics (standards of classifying or measuring), techniques (ways of classifying or measuring), and analytical frameworks (perspectives on the utility of classes or measures) is needed (Jeffrey \& Geary, 2004). Too often, the green urban agenda forgets the "green," concentrating on energy efficiency and resource management, neglecting the lifeenhancing and wonder-expanding dimensions of nature itself (Beatly, 2010). This study intends to contribute and meet the needs of incorporating green concepts in city infrastructure design.

\subsection{Overview}

Greening the city can be categorized and grouped into GI, green projects, green development and green approaches. One objective of this study is to define the start-up of a green development project, establishing an integrated green approach to land development and servicing infrastructure. GI can be defined differently, depending on the context in which it is used. Two main definitions of GI are used; some refer to trees in urban areas as GI because of the "green" benefits they provide, while others use GI to refer to engineered structures (such as water treatment facilities or a green roof) that are designed as environmentally friendly (Benedict \& McMahon, 2006).

Here, infrastructure is understood as the substructure system such as aqueducts and pipeline on which the growth of a community depends; while GI may be a resilient landscape that supports a multitude of ecological, economic, and social functions without compromising the sustainability of the resource base (Mell, Roe, \& Davies, 2009). GI is the physical environment within and between cities, towns, and villages. It is an interconnected network of open spaces, water bodies and environmental features, and the natural systems that these support (Davies, 2011). When hearing the term "infrastructure," most people think of gray infrastructure such as roads and sewers, or of social infrastructure such as hospitals and schools (Bao, 2010). In

the municipal world, these facilities are termed "built infrastructure." With this definition, GI could be defined as hard infrastructure built respecting green principles. 
The built infrastructure design approach needs to be matched to the European GI concept (the concept of hubs and connecting links), maintaining that engineered infrastructures will be designed to support the greening process; this approach is identified as integrated GI. Therefore, for GI to be an integrated concept, it should include both concepts in a single ideology, respecting ecology and mimicking nature. Taking a greener approach to infrastructure development not only mitigates the potential environmental effects of development (e.g. improving stream health and reducing energy use) but makes economic sense also, when considering the influence of conventional development on "natural capital" and the services rendered by natural capital (Olewiler, 2004).

There has been a reluctance to use GI in new developments because it is untested (Alexander \& Tomalty, 2002). In 2013, this statement remains accurate. This essay provides a literature review of the available approaches for initiating green development.

\subsection{General Practices}

Most papers in the literature focus on individual aspects of green development and in urban planning. For instance, Tzoulas et al. (2007) formulated a conceptual framework of associations between urban green space, ecosystems, and human health. Benedict and McMahon $(2002$; 2006) focused on land conservation, defining a vision to face the challenges brought by population growth and proposing to build conservation networks that link land for nature and people. McDonald et al. (2005) also proposed a framework based on a landscape approach. Other examples include Mavsar (2010), who developed the forest component of GI, Amati and Taylor (2010) who studied green belts, and Lehmann (2010), who developed some of the green urbanism principles. Douglas Farr (2008) promoted sustainable planning to support sustainable urbanism in urban design, phasing with nature. Sim Van Der Ryn proposed ecological design (Van Der Ryn \& Cowen 2007).

Green infrastructures are typically integrated into the process of urban greening and may follow different approaches to attack urban planning and sustaining green cities. Transportation, clean air, population density, health, and water are topics considered in the philosophy of urbanization. Many of the different trends proposed to develop a concept of urbanization are presented below.

Lehmann (2010) proposed the principles of green urbanism, laid out as a step-by-step manual that can be adjusted for application in various contexts. These principles contain a series of pillars that include energy conservation, the use of new technologies (such as combined heat-and-power or solar cooling), the use of renewable energy sources (such as solar PV, solar thermal, wind on land and offshore, biomass, mini hydro, and geothermal), and the concept of the city of short distances, resulting in multiple benefits for both the environment and the economy (Lehmann, 2010).

Wheeler and Beatly (2009) proposed an approach to sustainable urban development in The Sustainable Urban Development Reader, presenting an overview of the field by various authors. The topics covered include land use and urban design, transportation, ecological planning and restoration, energy and materials use, economic development, social and environmental justice, and green architecture and building (Wheeler \& Beatly, 2009). The edition asks basic questions: what will our cities and suburban landscapes be like in fifty 
and in one hundred years? How can we plan and develop communities that will meet long-term human and environmental needs? The concept of sustainable urban development enables citizens, planners, and policy makers worldwide to explore these questions (Wheeler \& Beatly, 2009).

Ritchie and Thomas (2009) published Sustainable Urban Design: An Environmental Approach. The book, written with many contributors, identifies major issues in making cities environmentally sustainable. It is vital to move towards sustainability in urban forms, transport, landscape, buildings, energy supply, and all other aspects of city living (Ritchie \& Thomas, 2009). Ideas of planning, space and form are a backdrop to many of the points made, but the built environment already suffers from those too confident of their solutions and those who think in "silo"-based terms, over-planning and overconstraining development. The book's contributors believe that an integrated approach is needed (Ritchie \& Thomas, 2009).

Beatly and Newman (2009) offer Green Urbanism Down Under. Beatly previously wrote Green Urbanism: Learning from European Cities (1999), which documents the urban ecology and green urban planning work in 30 European cities. Green Urbanism Down Under explores positive stories of innovative practice in Australia. Australia represents a good model to illustrate the adage "Think globally, act locally." Australian cities use a variety of planning instruments-including land use and community plans-to give meaning to sustainability (Beatly \& Newman, 2009).

Frumkin, Frank and Jackson (2009) proposed urban planning with a health perspective. Urban Sprawl and Public Health: Designing, Planning and Building examines how the built environment affects the population and how building smarter can promote health and well-being and protect the environment. The authors take the approach that both land use and transportation are intrinsic to sprawl, promoting densification of the city to reduce its development footprint.

Birch and Wachter's (2008) Growing Greener Cities is a collaboration with different authors, presenting an overview of green and sustainable cities and providing tools for measuring and managing success. The book covers most urban green issues. The authors wrestle with the difficulties of breaking old, anti-greening habits and introducing new practices, detailing successful strategies and practices ranging in scale from regional watershed management to rain barrel placement (Birch \& Wachter, 2008).

Van Der Ryn and Cowen (2007) proposed a new concept of ecological design in the first edition of Ecological Design published in 1999; a benchmark, pioneering work in ecodesign. It is not a design handbook but a quest toward creating a design process that has the preservation and restoration of the ecological commons at its core (Van Der Ryn \& Cowen, 2007).

Most of these concepts or approaches do not propose an integrated framework. There is a lack of structure to organize the work of professionals in different specialties from start-up to delivering a final plan. Existing planning and development models do not offer a holistic approach for addressing water issues. Only two of these publications address water as an important element in sustainable development.

Novotny, Ahern and Brown (2010) published Water Centric Sustainable Communities, combining landscape, water management, transportation, infrastructure, and triple bottom line assessment into an integrated system, covering best practices in GI and 
sustainable development. Reuse is becoming a necessity since a city and its water and waste management cannot be separated from its potable water sources. A city cannot have an unsustainable, adverse effect on downstream users and other cities (Novotny et al., 2010).

Sarté (2010) wrote Sustainable Infrastructure, The Guide to Green Engineering and Design, offering an extensive examination of sustainable engineering practices in an urban design context. It addresses the processes and systems of sustainable design for greening infrastructure. It also offers a technical, guided approach to working with water, wastewater, energy, and site design. Creating GI involves designing regenerative systems and establishing new ecologies that thrive (Sarté, 2010). Sarté discusses framework approaches to structure the organization of a project, describing in detail four frameworks: 1) pillars of sustainability; 2) the scale density framework; 3) the transect; and 4) the built form-ecology framework. These frameworks are the matrix used to identify elements covered by a sustainable project.

These two books present an extensive description of techniques to improve sustainability, although neither presents a formal framework for initiating a project. Extending these proposals, the present study proposes to fix water as the central element of any green concept of housing development and offers a start-up framework to initiate a planning process.

In Europe, green practices have previously been introduced in infrastructure design without an over-arching framework. The concept of sustainability has been taken into account together with the ecological aspect in decision-making for urban infrastructure selection. Urban planners and civil engineers have tried to respect the Brundtland Commission's definition of sustainability in designing infrastructure, which states that sustainability is development that meets the needs of the present without compromising the ability of future generations to meet their needs (WCED, 1987).

In 2009, Natural England published this GI guidance:

Green Infrastructure is a strategically planned and delivered network comprising the broadest range of high quality green spaces and other environmental features. It should be designed and managed as a multifunctional resource capable of delivering those ecological services and quality of life benefits required by the communities it serves and needed to underpin sustainability. Its design and management should also respect and enhance the character and distinctiveness of an area with regard to habitats and landscape types (Natural England, 2009, p. 7).

In France, the concept of trame écologique was developed from 1990 to 2000. In the following years, numerous regions implemented the concept and in 2010, Allog-Dhuise updated the original document. The term "green infrastructure and blue" was chosen to reflect the new, dual concept, reflecting the importance of provinces and departments expressing their view on the spatialization of this issue. In 2004/5, DIREN RhôneAlpes, associated with the Loire DDE conducted an experiment in this direction in the territory of South SCoT Loire (Chatain, 2005). France focuses on the broad concept of sustainable development and has adopted a green development strategy. Trame verte et bleu includes the concept of hubs and corridors and ecology networks are seen as the key to conserving biodiversity. 
In the US, the notion of (low impact development (LID) has been formally structured since 1998, when the Low Impact Development Center (LIDC) was established to design and provide information about new stormwater management techniques. Leadership in energy and environmental design (LEED) was developed in 2002 by the US Green Building Council (USGBC), providing building owners and operators with a concise framework for identifying and implementing practical and measurable green building design, construction, operations, and maintenance solutions (USGBC, 2009).

In Shanghai, GI entails an increase in green spaces in the city. Park departments propose a scientific approach to ensure that all citizens live within two kilometers of a green space (park). An extensive program to develop public parks within the city is currently being implemented.

In Australia, GI presently focuses mainly on green roof and green wall design because many green practices have already been introduced into design practices. Water sensitive urban design (WSUD) has evolved from its earlier association with stormwater management to provide a broader framework for sustainable urban water management, now offering a framework for common and unified methods of integrating the interactions between the urban built form (including urban landscapes) and the urban water cycle (Wong, 2006). GI is the network of designed and natural vegetation found in cities and towns, including public parks, recreation areas, remnant vegetation, residential gardens and street trees, as well as innovative and emerging new urban greening technologies such as the green roof and the green wall (Barlow, 2009).

In 2006, Mitchell explored Australian experiences in the application of the concept of integrated urban water management (IUWM) to land development sites. The understanding of IUWM is maturing within the Australian water industry. Successful projects include the translation of IUWM concepts into well-functioning operational urban developments, significant reductions in the effect of the urban developments on the total water cycle, and the increasing acceptance of the concept within the water and land development industries (Mitchell, 2006). However, there is room for greater integration of the water supply, stormwater, and wastewater components of the urban water cycle, improved dissemination of knowledge, enhancement of skills in both public and private organizations, and in monitoring the performance of systems and technologies (Mitchell, 2006).

In Western Canada, the development of GI is promoted through partnership between the public, government departments, and the private sector. Formal organizations were established in 2006. In Ontario in 2008, the City of Toronto developed the Green Development Standards. Tables that outline the wet weather flow management guidelines for Toronto form one example of the guidelines that make up these standards. The standards also cover the Better Buildings Partnership guidelines. Other terms originating from the same source as LID include sustainable urban drainage systems, innovative or integrated stormwater management, WSUD, GI design, ecological engineering, and the LEED for neighborhood development (LEED ND) (Gyurek, 2009).

There is a multitude of approaches to managing environmental projects. Some authors propose holistic approaches for planning projects. In 2004, John Randolf published Environmental Land Use Planning and Management, a textbook that presents a comprehensive 
approach to issues of land use planning and management. The author described basic knowledge in planning theory and natural science, focusing on land planning.

In 1996, the EPA (Environmental Protection Agency) entered into a cooperative agreement with the American Society of Civil Engineers led by members of the Urban Water Resources Research Council to initiate the International Stormwater Best Management Practices Database Project (BMP Database). The BMP Database goals were multi-faceted, although key goals include the development of a standardized set of monitoring and reporting protocols for urban stormwater BMP performance studies. The 2012 version of this monitoring manual includes stormwater management practices and a planning approach (WERF,2012). Again, this approach focuses on a specific topic: stormwater management. The methodology provides an eight-step approach for developing a monitoring plan including defining study objectives, identifying study goals, identifying information inputs/data needs, defining study boundaries, developing an analytical approach, specifying performance or acceptance criteria, developing a detailed plan for obtaining data, and assessing the reasonableness of the plan and refinement.

In 2009, the EPA's Smart Growth Program in conjunction with the Office of Water edited the Water Quality Scorecard, incorporating GI practices at the municipal, neighborhood, and site levels. This scorecard offers policy options and a systematic approach for management across multiple municipal departments, proposing designmanaging parameters for municipal officers. Again, this approach is oriented to stormwater management.

LID techniques were pioneered by Prince George's County, Maryland, in the early 1990s. The first methodology proposed by the Department of Environment of Maryland is now used by most practitioners and many states in the US. Again, this approach was designed to manage stormwater.

A universal methodology including all aspects of GI and encompassing the different specialties is required. In Canada, the British Columbia (BC), Alberta, Manitoba, and Ontario approaches have been proposed through partnerships with stakeholders. One outcome has been the development of the BC guidebook in 2002, which has since become a reference on GI in Canada (BCWWA, 2010). However, these approaches continue to focus heavily on stormwater management.

Practitioners require short, comprehensive guidelines to plan their projects. LEED is now a reference for green buildings. In 2010, the USGBC developed the LEED ND rating system to guide and assess sustainable community development, the most recent contribution to GI planning. As it is a qualification program, the reference is a rating system, explaining how to guide development and redevelopment projects toward more sustainable design. It is not considered a universal approach. This study investigates these references to determine systemic activities to initiate and develop a new green project.

\subsection{Concepts and Approaches 2.3.1 Specific Frameworks}


Leaders and members of professional associations in many disciplines have realized that the current infrastructure and urban planning paradigms have become impediments to achieving sustainable urban development and living (Novotny et al., 2010). Many concepts and approaches have been developed and the most referenced are presented below.

\subsubsection{American Institute of Architects (AIA) Committee on the Environment: Ten Measures of Sustainable Design}

"The Committee on the Environment (COTE) works to advance, disseminate, and advocate design practices that integrate built and natural systems and enhance both the design quality and environmental performance of the built environment"; COTE serves as the community and voice on behalf of AIA architects regarding sustainable design. COTE's ten measures of sustainable design and performance metrics are: 1) sustainable design intent and innovation, 2) regional/community design and connectivity, 3) land use and site ecology, 4) bioclimatic design, 5) light and air, 6) water cycle, 7) energy flows and energy future, 8) materials and construction, 9) long life, 10) loose fit, and collective wisdom and feedback loops (AIA, 2012).

\subsubsection{American Society of Landscape Architects (ASLA) Sustainable Sites Initiative Benchmarks and Performance Guidelines}

The Sustainable Sites Initiative is an interdisciplinary effort by the American Society of Landscape Architects, the Lady Bird Johnson Wildflower Center at The University of Texas at Austin and the United States Botanic Garden to create voluntary national guidelines and performance benchmarks for sustainable land design, construction and maintenance practices; The Meadows Foundation and Landscape Structures (ASLA, 2009) provide major funding for the Sustainable Sites Initiative. The framework is presented in nine topics: 1) site selection; 2) pre-design assessment and planning; 3) site design — water; 4) site design—soil and vegetation; 5) site design—-materials selection; 6) site design-human health and well-being; 7) construction; 8) operations and maintenance; and 9) monitoring and innovation (ASLA, 2009).

\subsubsection{BREEAM}

"BREEAM (building research establishment environmental assessment method) is a building certification system established in 1990. It is a method of environmental auditing, providing a set of standards for best practice in sustainable development for the design, construction, operation and environmental performance of buildings"; The main criteria for calibration include measures affecting energy, water use, indoor environment, pollution, transport, materials, waste, ecology, and management processes (BREEAM, 2012).

\subsubsection{Light Imprint}

LINU (light imprint new urbanism) is a technical development based on the principle of minimum loan territory by coordinating the engineering principles of new urbanism 
and sustainability, offering a set of solutions through transitional areas. Light imprint principles are formatted in a handbook and the light imprint matrix is the primary organizing method.

'The Light Imprint Handbook is a quick reference to which tools can be utilized to best implement light imprint (LI) techniques, also demonstrating where tools are most appropriately located along the transect. The transect zone matrix is designed to serve as an organizational framework and is by its nature somewhat subjective; the LI team suggests where on the rural to urban scale each tool is most useful depending on location on the transect; each project has a specific set of needs" (CNU, 2012).

To create a simple framework, the LI tools are classified into four main categories: paving, channeling, storage and filtration; some tools can be used for more than one function. The LI team's approach is to classify most tools by their principal function and refer to their benefits in other categories; over sixty tools are provided to apply solutions for different applications (CNU, 2012).

\subsubsection{Living Building Challenge}

'This approach is also a certification program designed on the basis of conservation and restoration and is an integrated tool that can be applied to landscaping, infrastructure, renovations to buildings, campus and community development. The Living Building Challenge is comprised of seven performance areas, or "petals": site, water, energy, health, materials, equity and beauty. Petals are subdivided into twenty imperatives, each focusing on a specific sphere of influence. This compilation of imperatives can be applied to almost every conceivable typology or project type, whether a building (the renovation of an existing structure or new construction), infrastructure, landscape or community development. Naturally, strategies to create living landscapes, infrastructure, renovations, buildings or neighborhoods will vary widely by occupancy, use, construction type and location, but the fundamental considerations remain the same" (ILFI, 2012).

\subsubsection{Melbourne Principles for Sustainable Cities}

At an international conference in Australia on 2 April 2002 was organized by the United Nations Environment Programme (UNEP) and the International Council for Local Environmental Initiative. Ten principles of sustainable development were outlined to create a comprehensive framework for building better towns.

The Melbourne Principles are intended to guide thinking and provide a strategic framework for action; they are not prescriptive, allowing cities to develop sustainable solutions relevant to their particular circumstances. They can help to bring together citizens and decision-makers, whose participation and cooperation is essential in transforming cities to sustainability. The principles are: 1) provide a long-term vision for cities based on sustainability, intergenerational, social, economic and political equity, and their individuality; 2) achieve long-term economic and social security; 3) recognize the intrinsic value of biodiversity and natural ecosystems, and protect and restore them; 4) enable communities to minimize their ecological footprint; 5) build on the characteristics of ecosystems in the development and nurturing of healthy and sustainable cities; 6) recognize and build on the distinctive characteristics of cities, including their human and 
cultural values, history and natural systems; 7) empower people and foster participation; 8) expand and enable cooperative networks to work towards a common, sustainable future; 9) promote sustainable production and consumption through appropriate use of environmentally sound technologies and effective demand management; and 10) enable continual improvement based on accountability, transparency and good governance (UNEP, 2002).

\subsubsection{Net-Zero Energy Development}

'In 2003, a group of homebuilders and developers began informal discussions on new decentralized energy systems and how future Canadian homes could be better designed to respond to Canada's clean air and climate change objectives". In 2006, the coalition was incorporated as a not-for-profit organization to promote energy efficiency in homes. The Net-Zero Energy Home Coalition (NZEH) promotes the development of homes that consume a small amount of energy, focusing its efforts on activities that have the greatest influence on achieving the goals of reducing energy consumption (Net-Zero Energy Home Coalition, 2012). Currently, the coalition extends to North America, creating a large membership including 361 architects.

\subsubsection{One Planet Living's Ten Principles}

'The One Planet Communities program is creating a network of the earth's greenest neighborhoods. One Planet Living is a model based on ten simple principles which provide a framework to make sustainable living easy and affordable for all" (Riddlestone 2013). The One Planet Communities program uses ten guiding principles as a framework to help partners examine the sustainability challenges they face and develop appropriate solutions. These principles were developed as a result of lessons learned from BioRegional's work at the pioneering BedZED eco-village in South London. The ten principles of One Planet Living are: 1) zero carbon; 2) zero waste; 3) sustainability; 4) transporting sustainable materials; 5) local and sustainable food; 6) sustainable water; 7) land use and wildlife; 8) culture and heritage; 9) equity and local economy; and 10) health and happiness. One Planet Living uses ecological footprinting as its key indicator of sustainability (One Planet Living, 2012).

\subsubsection{Permaculture}

"Permaculture is a design system for sustainable development that affects all aspects of the human environment. The system teaches how to build eco-homes, grow food, restore the landscape, restore ecosystems, recover rainwater and build new communities'. This approach has been recognized in more than 20 countries since 1985". There are 12 permaculture design principles: 1) observe and interact; 2) catch and store energy; 3) obtain a yield; 4) apply self-regulation and accept feedback; 5) use and value renewable resources and services; 6) produce no waste; 7) design from patterns of nature; 8) integrate rather than segregate; 9) use small and slow solutions; 10) use and value diversity; 11) use edges and value the marginal; and 12) creatively use and respond to change (Permaculture Institute, 2012).

\subsubsection{Regenerative Development}


'During the late 1970s, John T. Lyle (1934-1998), a Cal Poly Pomona landscape architecture professor, challenged graduate students to envision a community in which daily activities were based on the value of living within the limits of available renewable resources without environmental degradation. Over the next ten years, students and faculty researched the possibilities of creating a community that made use of on-site resources, operated with renewable energy, and worked with biologically based processes" (Lyle Center, 2013). The concept seeks to develop an environment that enhances human activities from a personal residence to a complete district, creating human-made surroundings that provide the setting for human activity, ranging from large-scale civic surroundings to personal spaces (Jenkins, 2009).

\subsubsection{Rocky Mountain Land Use Institute's Urban Framework}

"The Rocky Mountain Land Use Institute (RMLUI) Sustainable Community Development Code Framework is sustainable at its core, multidisciplinary in its approach, and contextually oriented. It fully encompasses environmental, economic, and social equity. It is innovative and distinctive by linking natural and manmade systems, incorporating useful features of other zoning systems (e.g. performance and form based), and responds to regional climate, ecology, and culture. The basic organization and approach to each topic is to examine relevant obstacles, incentives, and regulations" (RMLUI, 2009). The Framework incorporates sustainability principles and practices, takes a multi-disciplinary approach, promotes triple bottom-line (environment, economy and social equity), is innovative and distinctive, links natural and human-made systems, incorporates useful features of other zoning systems, responds to regional climate, ecology and culture, identifies relevant obstacles, incentives and regulations (Shutkin \& Duerksen, 2011).

\subsubsection{SmartCode}

"SmartCode is a proposal for a unified development plan for land, presenting a vision codifying zoning, subdivision rules, urban design and architectural options. The code develops a community vision for different avenues of development, taking into account the human habitat of a rural aspect to the urban environment, also applying the principle of transit areas" (CATS, 2012). "The SmartCode is a tool that guides the form of the built environment to create and protect development patterns that are compact, walkable, and mixed use; these traditional neighborhood patterns tend to be stimulating, safe, and ecologically sustainable. The SmartCode requires a mix of uses within walking distance of dwellings so residents are not forced to drive everywhere; it supports a connected network to relieve traffic congestion. Simultaneously, it preserves open lands, as it operates at the regional and community scales" (CATS, 2012).

\subsubsection{Ascertainment}

Many of these concepts refer to LID techniques and to LEED. LEED has become a measure of acceptance for new buildings and subdivisions in developed countries (Novotny et al., 2010). The International Water Association Panel considers LID as a 
green scenario (Novotny et al., 2010). In this study, four main frameworks were identified as more referenced. The next section presents these concepts and their frameworks.

\subsubsection{The LID Concept}

LID is a low cost, effective alternative to stormwater control technology combining resource conservation in a hydrological functional site design with pollution prevention measures to reduce developmental effects, replicating natural watershed hydrology and water quality. Through a variety of small-scale site design techniques, LID controls runoff discharge, volume, frequency and quality to improve development runoff conditions (LIDC, 2011a).

The LIDC was established in 1998 in the US to promote the use of LID and other sustainable stormwater management techniques. The center's mission is to help communities and institutions address increasingly complex and critical issues associated with their resource protection programs and stormwater management regulations. The organization is a multidisciplinary group of technically skilled professionals seeking to develop new approaches to stormwater management, demonstrate their effectiveness, and assist in integrating them into master planning activities, manuals of practice, and personnel training:

The source control of the LID concept is quite different from conventional treatment (pipe and pond stormwater management site design). Hydrologic functions such as infiltration, frequency, and volume of discharge, and ground water recharge can be maintained with the use of reduced impervious surfaces, functional grading, open channel sections, disconnection of hydrologic flow paths, and the use of bioretention/filtration landscape areas. LID also incorporates multifunctional site design elements into the stormwater management plan. Such alternative stormwater management practices such as on-lot micro storage, functional landscaping, open drainage swales, reduced imperviousness, flatter grades, increased runoff travel time, and depression storage can be integrated into a multifunctional site design (LIDC, 2011b).

\subsubsection{The LID Approach}

In the US, many states are developing tools to manage LID programs. For example, in 1999, the Maryland Department of Environmental Resources presented a structured approach, proposing to initiate projects using the five steps listed below.

\subsubsection{Site Planning}

Fundamental concepts that define the essence of LID technology must be integrated into the site planning process to achieve a successful and workable plan. These concepts include using hydrology as the integrating framework, micromanagement, controlling stormwater at the source, using simplistic, non-structural methods, and creating a multifunctional landscape.

\subsubsection{Hydrologic Evaluation}


The purpose of the hydrologic evaluation is to determine the level of control required to achieve stormwater management goals for LID sites. The required levels of control may be achieved through the application of various hydrologic tools during the site planning process, the use of integrated management practices (IMP), and supplemental controls. The hydrologic evaluation is performed using hydrologic modeling and analysis techniques. The output of the hydrologic analysis provides the basis for comparison with four evaluation measures (runoff volume, peak runoff, frequency, and water quality control).

\subsubsection{Integrated Management Practices}

LID IMP are designed for on-lot use. This approach integrates the lot with the natural environment and eliminates the need for large, centralized parcels of land to control endof-pipe runoff. The challenge of designing a low impact site is that the IMP and site design strategies must provide quantity and quality control and enhancement. This includes ground water recharge through infiltration of runoff into the soil; retention or detention of runoff for permanent storage or for later release; pollutant settling and entrapment by conveying runoff slowly through vegetated swales and buffer strips; and multiple uses of landscaped areas.

\subsubsection{Erosion and Sediment Control}

Erosion and sediment control and stormwater management are closely interrelated. The application of LID concepts and the associated emphasis on minimizing the areas disturbed and breaking up drainage areas into small, manageable sub-catchment areas is in harmony with the basic principles of erosion and sediment control.

\subsubsection{Public Outreach Program}

Both the public and developers must be committed to the program and a public consultation process is essential. The LID manual presents a strategy in four steps: 1) define objectives; 2) identify target audiences; 3) develop outreach materials; and 4) distribute outreach materials (Prince George's County 2008). The program can be tailored to specific audiences with a specific message to each audience. Seen as an education program, it can identify several objectives, create marketing tools, promote stewardship to initiate environmental protection measures, show potential cost savings, encourage a sense of community, and ensure proper maintenance measures.

LID is one of the fundamental elements of the framework proposed to initiate new developments. The Maryland Department of Environmental Resources developed a LID framework to initiate a project that considered as one of the baseline scenarios to develop a new framework.

The next section presents LEED, the green scenario preferred by urban development professionals.

\subsubsection{The LEED Concept}

LEED is an internationally recognized green building certification system that provides third-party verification that a building or district was designed and built using strategies aimed at improving performance across all metrics (LEED 2012). These metrics include 
energy savings, water efficiency, $\mathrm{CO} 2$ emissions reduction, improved indoor environmental quality, and stewardship of resources and sensitivity to their effects (USGBC). There are six categories of certification: (1) new construction; (2) commercial interiors; (3) core and shell; (4) existing buildings; (5) homes; and (6) neighborhood developments. In the US, the USGBC manages the certification program while the Canada Green Building Council (CaGBC) manages the program in Canada. The two organizations are independent, although the US certification may accredit Canadian projects. For example, the Toronto Waterfront Project was certified LEED ND Gold by USGBC.

As LEED is mostly dedicated to buildings, the USGBC has developed the LEED for neighborhood development (LEED ND) rating system to guide and assess sustainable community development. The 2009 LEED ND, for example, is a set of performance standards for certifying the planning and development of new neighborhoods. The intent is to promote healthful, durable, affordable, and environmentally sound practices in building design and construction.

Prerequisites and credits in the rating system address five topics: smart location and linkage, neighborhood pattern and design, GI and buildings, innovation and design process, and regional priority credit. The system was created as a partnership between the USGBC, the Natural Resources Defense Council, and the Congress for the New Urbanism (CNU) and registration opened in April 2010.

The CNU is the leading organization promoting workable, mixed-use neighborhood development, sustainable communities, and healthier living conditions and is one of the major leaders of LEED. The $\mathrm{CaGBC}$ has developed the Canadian Alternative Compliance Paths (ACP) for the LEED ND 2009 rating system. The ACP are formally approved approaches that provide clarity and guidance for Canadian projects, addressing sections of the rating system that contain US-specific standards or wording (CaGBC, 2012).

\subsubsection{The LEED Approach}

Under the LEED approach, projects are accredited using a rating system. After registration, the project design team begins to collect information and perform calculations to satisfy prerequisite and credit documentation requirements. To start a project, LEED concentrates on planning following several basic steps, as outlined here.

\subsection{Site Analysis and Programming}

This includes property selection, stakeholder identification and outreach, information gathering, environmental review, conceptual planning and development programming.

\subsection{Preliminary Planning}

This includes the initial planning for land use, transportation networks and major facilities, public outreach and the refinement of plans.

\subsection{Final Design}

This includes continued public outreach, preparation of the final site plan, infrastructure and building design, and the acquisition of a construction permit. LEED 
accreditation will be given if a score of 40 (Certified), 50 (Silver), 60 (Gold), or 80 (Platinum) is obtained. The total number of awardable points is 110 , comprising 27 points for smart location and linkage, 44 points for neighborhood pattern and design, 29 points for GI and buildings, six points for the innovation and design process, and four points for regional priority credit. A detailed scorecard is published by the USGBC as a project checklist. The accreditation process follows these steps: registration, smart location, and linkage prerequisite review, conditionally approved plan, pre-certified plan, and certified neighborhood development.

LEED is one of the most widely used standards in the US (Sarté, 2010). While the qualifications of LEED are very developed, initiating a project from these criteria remains tedious. Nevertheless, the proposed framework to manage a LEED project is considered by many urban development professionals as a baseline. The framework proposed by LEED is one of the four approaches used in this paper to develop a formulation of synthesis. One of the weaknesses of LEED is the fact that the framework is focused mainly on new development and is not adapted to brownfield development.

The next section presents the US EPA proposal to formulate a green development project.

\subsubsection{US Environmental Protection Agency Green Approach}

The US EPA promotes GI development, in particular through publishing a series of documents to support stakeholders interested in introducing green action in projects.

\subsubsection{Municipal Handbook}

The EPA has developed a Municipal Handbook (USEPA, 2012), a series of documents aimed at helping local officials implement GI in their communities. The documents cover specific terms to help municipalities introduce GI in the design of storm management facilities. One chapter identifies and discusses the most common funding options available to communities for funding green stormwater infrastructure, stormwater fees, and loan programs. Another chapter covers street design and various other topics are also discussed. Additionally, the EPA has developed the Water Quality Scorecard (US EPA, 2009).

\subsubsection{Water Quality Scorecard (EPA 231-B-09-001)}

The EPA's Water Quality Scorecard was developed to assist local governments in identifying opportunities to remove barriers and revise and create codes, ordinances, and incentives for better water quality protection. It guides municipal staff through a review of relevant local codes and ordinances across multiple municipal departments at the three levels of a local government (municipality, neighborhood, and site) to ensure these codes work together to protect water quality goals.

The two main goals of this tool are to help communities protect water quality by identifying ways to reduce the amount of stormwater flows in a community and to educate stakeholders on the wide range of policies and regulations that affect water quality (US EPA, 2009b). In Canada, the provinces mainly manage their green scenario approaches. 
In Quebec, the Sustainable Development Act was adopted in 2006, recognizing "the character inseparable from environmental, social and economic activities development." The law proposes to sustain development through the inclusion of a set of 16 sustainable development principles. Nevertheless, there is no formal green scenario proposed as a framework to organize urban development. Conversely, most provinces orient their sustainable development strategy to climate change actions, adopting a strategy to manage river basins. Green scenario action plans are proposed in Alberta and BC and in Ontario, cities like Toronto have a program. The next section presents Alberta's LID.

\subsubsection{The Alberta Low Impact Development Partnership Approach}

The Alberta Low Impact Development Partnership (ALIDP) approach was created in 2004 to address the need to protect and maintain the integrity of the natural environment, while promoting growth, prosperity, and quality of life in Alberta's communities. The formal creation of the ALIDP Society occurred two years later, in 2006. The ALIDP has a diverse base including municipal and provincial governments, watershed stewardship groups, universities, corporations, and individuals with an interest in promoting LID practices. The Edmonton LID Conference (29 September 2009) covered a series of topics to qualify LID actions. The conference presented examples and lessons learned from different projects implemented mainly in Calgary and Edmonton. From the point of view of project preparation, Van Duin and Gyurek present an approach to LID planning.

Van Duin (2009) presented LID criteria. The rating system addresses environmental, economic, and social issues, allowing developers and their consultants, municipalities and the public to evaluate the relative merits of developments from a watershed protection perspective. The keystone of the matrix to rate a LID project should consider these criteria:

- objectives: no adverse effect on receiving water bodies

- strategies: control pollutant loading

- policy tools: land use bylaws, watershed plans, and master drainage plans

- technology/implementation tools: conduct pollutant loading, remove computation and implement all applicable source control practices.

Gyurek (2009) proposed LID as a multi-barrier approach that uses features at the lot, neighborhood, and watershed level to maintain on-site water balance. A multi-barrier approach at the lot level includes a green roof to reduce or delay runoff, the connection of downspouts to rain gardens and/or storage tanks and cisterns, minimum soil depth criteria, direct runoff to infiltration swales, and the use of harvested rainwater to irrigate vegetation or flush toilets.

A multi-barrier approach at the neighborhood-level may involve reduced road widths, using permeable pavement, the removal of curbs/gutters to direct runoff to swales, the promotion of infiltration box planters, the integration of natural wetlands, and/or the building of constructed wetlands to detain runoff, reduce total loadings, and convey parking lot runoff to swales, and bio-retention areas. 
A multi-barrier approach at the watershed level was proposed for the integration of natural wetlands with constructed wetlands for major drainage systems to rehabilitate degraded natural features such as wetlands or creeks, maintain natural stream channels, use wide riparian buffer strips, provide sufficient flooding areas in riparian zones, and to avoid direct discharge even after large rainfall events (Gyurek, 2009). The Alberta conference exposed the LID from a design point of view but exposes no formal framework. Nevertheless, the multi-barrier approach is a concept used to develop this paper's new, integrated concept.

Conversely, BC developed sustainability tools relatively early. Documentation is largely diffused on web sites and Canadian practitioners use many of the proposed guidebooks. The next section summarizes the $\mathrm{BC}$ approach.

\subsubsection{The British Columbia Approach}

In BC, the Rainwater Management and Green Infrastructure seminar was initiated by an inter-governmental partnership (IGP) on 11 June 2007. The Water Sustainability Action Plan for British Columbia provides a partnership umbrella for an array of on-theground initiatives that promote a "water-centric" approach to community planning and development. One of the tools developed under this umbrella is the water balance model for BC. Developed by an IGP (BC and Fisheries and Ocean Canada) as an extension of Storm Water Planning: A Guidebook for British Columbia, the water balance model enables users to visualize ways to implement GI solutions to achieve rainwater runoff source control at the site level. The Water Sustainability Action Plan for British Columbia is sponsored by the province of $\mathrm{BC}$, and its elements are delivered through partnerships.

Under the Action Plan umbrella, the Water Sustainability Committee of the BC Water and Waste Association is the managing partnership and is responsible for providing leadership, facilitation, and organizational services for program delivery. Basic information is provided in a guidebook, refocusing the approach to sustainable ecosystem management. The use of the term "stormwater" suggests there is a problem, whereas "rainwater" is seen as a resource (BCWWA, 2005). The past two decades has seen an evolution to an integrated approach.

The approach described in the guidebook also introduced the concept of performance targets to facilitate implementation of the integrated strategy for managing the complete rainfall spectrum. Rainfall capture means include measures such as rain gardens and infiltration soakaways, runoff controls (which delays overflow runoff by means of detention storage ponds), and flood mitigation (which reduces flooding by providing sufficient hydraulic capacity to "contain and convey") (BCWWA, 2005).

Defining rainfall tiers simply enables a systematic approach to data processing and identification of rainfall patterns, distributions, and frequency. The integrated approach proposed by the guidebook (BCME, 2013) is presented in seven steps:

(1) secure political interest and support;

(2) frame the watershed problems and opportunities through a land use working session, drainage working session, ecology working session, and interdisciplinary roundtable session;

(3) develop objectives and alternative scenarios through flood management scenario modeling and source control scenario modeling; 
(4) collect meaningful data and refine scenarios according to concurrent rainfall and stream flow data, data on soils and groundwater, water quality data, and data on fish and their habitats;

(5) evaluate alternatives and develop component plans;

(6) develop an implementation program;

(7) refine through adaptive management.

BC's approach is one of the frameworks used for analysis and some of its proposals should be adopted to develop a new framework.

\subsubsection{Differentiation}

The following table presents the main characteristics of each selected framework. The existing frameworks are prepared to respond to a specific topic. At origin, LID was proposed to solve stormwater management problems, not addressing integrated water resources management issues but only a single component. The Water Quality Scorecard addresses a municipality's need to organize the startup of a green project, focusing on institutional organization. LEED is a certification for green projects. The LEED ND addresses an approach to design new development but it does not consider principles of integrated water resource management. The BC guidebook was originally prepared to manage stormwater problems. In its second edition, the guidebook (BCME, 2013) focused on integrated water resource management, but the proposed framework is more a guideline for policy makers and institutional management. The book largely covers stormwater management practices.

These four approaches are presented in the following table alongside their main characteristic.

Table 1. Differentiation among approaches

$\begin{array}{llll}\text { Approaches } & \text { Focus } & \text { Strength } & \text { Weakness } \\ \text { LID } & \text { Storm management } & \text { Hydraulic analysis } & \begin{array}{l}\text { No water supply } \\ \text { No wastewater }\end{array} \\ & & & \text { No urban } \\ & & & \text { planning } \\ \text { WaterQuality Scorecard } & \text { Institutional } & \text { Policy issue } & \text { No water supply } \\ \text { (EPA) } & \text { organization } & \text { No wastewater } \\ \text { LEED (USGBC) } & \text { Urban planning } & \text { Land planning } & \text { No } \\ & & \text { standards } & \text { management } \\ & & & \text { No water supply } \\ \text { BC guidebook } & \text { Storm management } & \text { No wastewater } \\ & \text { Institutional policy } & \text { management } & \text { No water supply } \\ & & \text { No wastewater }\end{array}$

\section{Conclusion}

Most frameworks are designed to satisfy the specific needs of public servants or specific designated professionals like engineers, urban planners, architects or landscape architects. As an example, the MDDEFP (Québec Ministry of Sustainable Development, 
Environment, Fauna and Parks), adopted a new guide (2011) to manage stormwater, proposing to introduce LID techniques in managing stormwater and pipe sizing. There is no consideration to plan other components of urban planning or other components of infrastructure planning. There is a separate and specific approach to guide design of water supply facilities and a specific approach to design small or large wastewater treatment facilities, but no framework to integrate stormwater, water supply and wastewater with urban planning when creating a new urban development.

Any smart growth development should be planned with this new approach: following nature, water should be a central element of any new concept. There is a strong interaction between each element. Drinking water will become wastewater and rainwater will flow to a lake or a river. Policymaking is not an issue for designers, as it is more a municipal concern. In many cases, policy is already defined, becoming an existing parameter.

Two groups of authors have specifically examined the engineering of GI: in 2010, S. B. Sarté published Sustainable Infrastructure and Water Centric Sustainable Communities was published by Novotny et al. (2010). Sarté offers several forms of guidance for project planning, creating a unique approach for each project by combining different philosophy or development frameworks. Sarté identified 13 frameworks, the most popular being LEED and BREEAM. Four approaches were identified to analyze sustainable infrastructure and four existing frameworks to organize green projects were suggested:

- Framework 1: pillars of sustainability. This approach presents an analysis based on five elements: water, energy, materials, ecology and community. Analysis of the project is formatted in these terms and it is proposed to proceed with a development evolution of the design following five levels of progression.

- Framework 2: the scale density framework. The approach is defined in four words: water, wastewater, energy, solid waste. The needs analysis is defined according to four levels: the city, the district, the block and the building. The organization becomes a pyramidal structure and presents an overall picture of the final proposal.

- Framework 3: the transect. This approach defines territory into seven areas: T1 (natural), T2 (rural), T3 (suburban), T4 (general urban), T5 (urban center), T6 (urban core), and SD (special district). This approach is a form of territorial organization to establish a balance between each of the zones and to identify needs. The overall plan is determined based on a progression from one area to another by introducing measures of sustainable development.

- Framework 4: the built form-ecology framework. This approach interconnects human actions with natural ecological systems. The method uses drivers to guide development. On the horizontal axis are biodiversity, water, air, land and energy. The vertical axis is divided into habitation/settlement, industry/resource extraction and recreation. The principle consists of establishing an equilibrium balancing all these elements according to the criteria in the appropriate box.

All these approaches or developmental frameworks are elements of reflection appropriate to define a development project and to define a sustainable strategy. 
However, none define a formula to initiate a project and carry through to final detailed engineering. These frameworks are rhetorical guidelines to orient development. This paper seeks to create a practical approach to assemble the pillars of a new development, not excluding the use of these rhetorical frameworks to enhance the orientation and define goals.

Secondly, Ahern examines best practices for planning the urban environment in a sustainable manner. Ahern proposes to place water at the center of urban concerns. The concept of ecosystem services now provides a powerful, broadly accepted, logical argument for the protection and responsible development of landscapes justified by the specific functions that landscapes provide, often with direct and measurable economic benefits for human beings (Ahern, 2010). Ahern proposed a six step methodology: 1) ecosystem services (goals and assessments); 2) resilience factors; 3) resilience planning strategies; 4) developing scenarios; 5) urban resilience-sustainability planning; and 6) planning implementation-adaptation. Two elements for which this paper searches are included in this approach: a way to initiate a project and a water-centric approach. Nevertheless, it does not describe what to do or how to do it in detail. The new proposed framework should focus on the startup of new development projects with a water-centric approach.

From the current findings, four approaches were selected to use in developing a new startup framework: Maryland's LID approach was chosen from the US, as it was the first state to develop a strategy to implement LID techniques. The EPA's Water Quality Scorecard was selected, as the EPA is the American reference to assess environmental effects. The USGBC's LEED is an internationally recognized green building certification system and for this reason, it was selected as the NGO approach for further examination. Finally, BC's guidebook approach was selected from among the Canadian provinces because $\mathrm{BC}$ has been a proactive Canadian province in the implementation of environmental planning since 2000 (Water Sustainability Action Plan for BC), BCME (2010).

The new model should integrate the European concept of natural hubs and links with the American concept of GI. It also extends the stormwater management infrastructure approach with an idea of a looping water cycle, maximizing the reuse of wastewater and stormwater. The fundamental idea is to mimic nature and reuse water. In the context of worldwide soft water shortages (particularly in developing countries), maximizing water conservation, natural storage and water reuse will help to address this problem.

To develop a new urban project, studying and developing the concept in six steps is recommended:

1) prepare an inventory to take a picture of the site and understand the stakeholders' needs;

2) study hydrology and hydraulic assessment to understand the natural flow of water;

3) propose IMP to introduce the new concept of a closed loop;

4) develop land planning to mimic nature;

5) prepare a consultation to review the stakeholders' needs already identified in Step 1;

6) propose a master plan to define an initial solution to design the project.

Future GI research would include developing the proposed framework for initiating new projects. Different areas of research can be analyzed using the proposed 
approaches. The main objective of this framework is to integrate the work of many professionals. Other areas of further GI research can support a new conceptual development. Clearly, the introduction of green concept in design will meet the challenges of climate change, which could form another topic of research.

\section{References}

AIA. (2012). Committee on the environment (COTE). Retrieved from http://network.aia.org/committeeontheenvironment/home/

Allag-Dhuisme, F., Amsallem, J., Barthod, C., Deshayes, M., Graffin, V., Lefeuvre, C., Salles, E. (coord), Barnetche, C., Brouard-Masson, J., Delaunay, A., Garnier, C.C., \& Trouvilliez, J. (2010). Choix stratégiques de nature à contribuer à la préservation et à la remise en bon état des continuités écologiques_premier document en appui à la mise en oeuvre de la Trame verte et bleue en France. Proposition issue du comité opérationnel Trame verte et bleue. MEEDDM ed.

Alexander, D. \& Tomalty, R. (2002). Smart growth and sustainable development: Challenges, solutions and policy directions. Taylor \& Francis. doi: 10.1080/135498302200002757

Amati, M. \& Taylor, L. (2010). From green belts to green infrastructure. Planning, Practice and Research, 25(2) 143-155, Taylor \& Francis.

ASLA (American Society of Landscape Architects). (2009). Guidelines and performance benchmarks. The Sustainable Sites Initiative. http:/ /www.asla.org/sites.aspx

Bao, L. (2010). Green infrastructure application in the Chelsea River Subwatershed. Landscape Architecture \& Regional Planning Masters Projects, Paper 4. Amhearst: University of Massachusetts. Retrieved from http://scholarworks.umass.edu/cgi/viewcontent.cgi?article=1003\&context=larp_ms_pr ojects

Barlow, S. (2011). Land and food resources. Melbourne: The University of Melbourne.

Barthod, C. \& Deshayes, M. (2009). Trame verte et bleue, the French green and blue infrastructure. Ministère de l'Écologie, de l'Énergie du Développement durable et de l'Aménagement du territoire. Retrieved from: www.développement-durable.gouv

BCWWA Water Sustainability Committee, Inter-Governmental Partnership, Convening for Action on Vancouver Island, Water Bucket Website Partnership, Vancouver Island Coordinating Team, and Green Infrastructure Partnership with West Coast Environmental Law. (2010). Beyond the guidebook 2010: Implementing a new culture for urban watershed protection and restoration in British Columbia. Retrieved from http://wcel.org/resources/publication/beyond-guidebook-2010-implementing-newculture-urban-watershed-protection-and-

BCME British Columbia Ministry of Environment 2013; Stormwater Planning: A Guidebook for British Columbia. http:// www.env.gov.bc.ca/epd/ mun-waste/waste-liquid/stormwater/

BCME British Columbia Ministry of Environment (2010h): Sustainability Action Plan for British Columbia, http://waterbucket.ca/cfa/category/turning_ideas_into_action/

Beatly, T. (1999). Green urbanism: Learning from European cities. Island Press. Washington

Beatly, T. \& Newman, P. (2009). Green urbanism down under: Learning from sustainable communities in Australia. Island Press. Washington

Beatly, T. (2010). Biophilic cities: Integrating nature into urban design and planning. Washington, DC: Island Press. Washington

Benedict, M. \& McMahon, E. (2002). Green infrastructure: Smart conservation for the 21st century, Sprawl Watch Clearinghouse, Washington, DC. 
Benedict, M. \& McMahon, E. (2006). Green infrastructure: Linking landscapes and communities. Island Press, Washington, DC

Birch, E.L. \& Wachter, S.M. (2008). Growing greener cities: Urban sustainability in the twenty-first century. Philadelphia: University of Pennsylvania Press.

BREEAM (Building Research Establishment Environmental Assessment Method). (2012). About BREE $A M$. Retrieved from http://www.breeam.org/about.jsp?id=66

British Columbia Ministry of Environment. (2005). Stormwater planning guidebook for British Columbia. Retrieved from http://www.env.gov.bc.ca/epd/epdpa/mpp/stormwater/stormwater.html

British Columbia Inter-Governmental Partnership (BCIGP). (2003). Water balance model (WBM). Retrieved from http://www.waterbalance.ca

CATS (Center for Applied Transect Studies). (2012). Smart Code version 9.2. The Town Paper

Publisher. Retrieved from http://www.transect.org/codes.html

CaGBC 2012, LEED 2009 for Neighbourhood Development with Canadian Alternative compliance Paths retrieved from http://www.cagbc.org/Content/NavigationMenu/Programs/LEED/RatingSystems/N eighbourhooddevelopments/default.htm

Chatain, M. (2005). Infrastructures vertes et blenes: guides technique et méthodologique. Éditeur: DIREN Rhône-Alpes. Retrieved from http://www.observationurbaine.certu.equipement.gouv.fr/infrastructures-vertes-et-bleues-a174.html

City of Toronto. (2008). The Toronto green development standards. http://www.toronto.ca/planning/environment/index.htm

CNU (Congress for New Urbanism). (2012). Light imprint new urbanism. Retrieved from http://www.cnu.org/node/1209

Davies, C. (2011). Stockton Tees green infrastructures strategy. Retrieved from http://www.stockton.gov.uk/greeninfrastructure

Farr, D. (2008). Sustainable urbanism: Urban design with nature. (Foreword by Andres Duany). Wiley, Hoboken, New Jersey

Frumkin, H., Frank, L., \& Jackson, R. (2009). Urban sprawl and public health: Designing, planning, and building healthy communities. Island Press, Washington, DC

Gyurek, L. (2009). Overview and background of LID, city of Edmonton. The Edmonton LID Conference (September 29, 2009)

ILFI (International Living Future Institute). (2012). Living building challenge. Retrieved from https://ilbi.org/lbc

Inter-Governmental Partnership and Green Infrastructure Partnership. (2007). Beyond the guidebook: Context for rainwater management and green infrastructure in British Columbia. http://www.waterbucket.ca/cfa/sites/wbccfa/documents/media/403.pdf

Hobden, D.W., Laughton, G.E., \& Morgan, K.E. (2004). Green space borders: A tangible benefit? Evidence from four neighbourhoods in Surrey BC 1980-2001. Land Use Policy, 21(2). http://dx.doi.org/10.1016/j.landusepol.2003.10.002

Jeffrey, P. \& Geary, M. (2004). Integrated water resources management: Lost on the road from ambition to realization? In: WATERMAX Conference. Beijing, November 2004.

Jenkins, S. (2009). Towards regenerative development. Retrieved from www.planning.nz

Kloss, G. (2009). Managing wet weather with green infrastructure: Municipal handbook-Rainwater harvesting policies. US EPA. Retrieved from http://www.dep.wv.gov/WWE/Programs/stormwater/MS4/guidance/handbooks/Do cuments/Rain $\% 20$ water $\% 20$ harvesting $\% 20$ municipal $\% 20$ handbook.pdf

Lehmann, S. (2010). The principles of green urbanism. UNESCO chair in Sustainable Urban Development for Asia and the Pacific, Earthscan, London UK. 
LIDC (Low Impact Development Center). (2011a). Low Impact Development Center homepage. Retrieved from http://www.lowimpactdevelopment.org

LIDC (Low Impact Development Center). (2011b). Impact Development Center's sizing tool explained. Retrieved from http://www.lid-stormwater.net/bioretention/bio_sizing.htm

Lukes \& Kloss. (2009). Managing wet weather with green infrastructure: Municipal handbookGreen streets. US EPA. Retrieved from http://water.epa.gov/infrastructure/greeninfrastructure/upload/gi_munichandbook_gr een_streets.pdf

Mavsar, R. (2010). Benefit (value) transfer method. European Forest Institute. www.efimed.efi.int

McDonald, L., Allen, W., Benedict, M., \& O'Connor, K. (2005). Green infrastructure plan evaluation frameworks. Journal of Conservation Planning, 1(1), 12-43.

MDDEFP (Québec Ministry of Sustainable Development, Environment, Fauna and Parks) (2011) Guide de gestion des eaux pluviales, http://www.mddefp.gouv.qc.ca/eau/pluviales/guide.htm

Mell, I.C., Roe, M., \& Davies, C. (2009). Exploring the role of green infrastructure in the mitigation of climate change in the urban realm. Climate Change: Global Risks, Challenges and Decisions. IOP Publishing IOP Conf. Series: Earth and Environmental Science.

Mitchell, V.G. (2006). Applying integrated urban water management concepts: A review of Australian experience. Environmental Management, 37(5), 589-605. doi: 10.1007/s00267004-0252-1

Lyle Center. (2013). History of the Lyle Center. Retrieved from http://www.csupomona.edu/ crs/history.html

Natura 2000. (2006). Networking program. Retrieved from www.natura.org

Natural England. (2009). Green infrastructure guidance. Natural England 2009 catalogue code: NE176, p. 7. Retrieved from www.naturalengland.org.uk

Net-Zero Energy Home Coalition. (2012). Net-zero energy development. Retrieved from http:/ /www.netzeroenergyhome.ca/

Neumann, M. (2009). Village at Griesbach-A case study in LEED®-ND certification. Canada Lands Company.

Novotny, V., Ahern, J., \& Brown, P. (2010). Water centric sustainable communities. John Wiley \& Sons.

Olewiler, N. (2004). The value of natural capital in settled areas of Canada. Ducks Unlimited Canada and the Nature Conservancy of Canada.

One Planet Living. (2012). One Planet Living's ten principles. Retrieved from http:/ /www.oneplanetliving.net/what-is-one-planet-living/the-ten-principles/

Pennsylvania Environmental Council. (2009). Implementing green infrastructure: Developing a winning strategy to fund Philadelphia's ambitious visions.

Permaculture Institute. (2012). Sustainable living, practical learning. Retrieved from http://www.permaculture.org/nm/index.php/site/index/

Prince George's County Maryland Department of Environmental Resources. (2008). LID national manuals, programs and planning division (PGDER), with assistance from US

EPA

Retrieved

from

http://www.co.pg.md.us/Government/AgencyIndex/DER/ESG/manuals.asp

Randolf, J. (2004), Environmental Land Use Planning and Management, IslandPress, Washington

Raoult, P. (2010). The green and blue infrastructure in mainland France: Challenges and experiences_French environment round table. Retrieved from www.legrenelle-environnement.fr

Riddlestone, S. 2013, What is One Planet Living, www.bioregional.com

Ritchie, A. \& Thomas, R. (2009). Sustainable urban design: An environmental approach (2nd ed.). Taylor \& Francis.

RMLUI. (2009). Sustainable community development code: A code for the 21 st century. 
Rottle, N.D. (2010). Integrating urban green infrastructure through collaborative visioning: New partners for smart growth. Seattle, Washington: Green Futures Lab, Department of Landscape Architecture, University of Washington.

Sarté, S.B. (2010). Sustainble infrastructure: The guide to green engineering and design. John Wiley \& Sons.

Shutkin, W. \& Duerksen, C. (2011). Sustainable communities start with sustainable community development codes. Rocky Mountain Land Use Institute. Retrieved from http://www.law.du.edu//rmlui

Tzoulas, K., Korpela, K., Venn, S., Ylipelkonen, Kazmierczak A., Niemela, \& James P. (2007). Promoting ecosystem and human health in urban areas using green infrastructure: A literature review. Landscape and Urban Planning.

UNEP (United Nation Environmental Program). (2002). Melbourne principles for sustainable cities. International Environmental Technology Centre. Retrieved from http://www.unep.org/ietc/

US EPA. (1999a). Low-impact development design strategies: An integrated design approach. EPA 841-B-00003.

US EPA. (1999b). Low-impact development hydrologic analysis. EPA 841-B-00-002.

US EPA. (2009a). Managing wet weather with green infrastructure. Washington, DC: United States Environmental Protection Agency.

US EPA. (2009b). Water quality scorecard, incorporating green infrastructure practices at the municipal, neighborhood, and site scales. Retrieved from http://www.epa.gov/owm/mtb/mtbfact.htm

US EPA. (2010). Managing wet weather with green infrastructure. Retrieved from http://cfpub.epa.gov/npdes/home.cfm?program_id=298

USGBC. (2009). LEED for neighborhood development.

USGBC. (2011). A local government guide to LEED neighborhood development. Retrieved from www.usgbc.org/nd

Van Der Ryn, S. \& Cowen, S. (2007). Ecological design (10th anniversary ed.) Washington: Island Press.

Van Duin Bert. (2009a). LID criteria, city of Calgary.

Van Duin Bert. (2009b). LID vs traditional subdivision study, city of Calgary.

WCED. (1987). Our common future: World Commission on Environment and Development (The Brundtland report). Oxford: Oxford University Press.

WERF,2012, International Stormwater BMP Database, www.bmpdatabase.org

Wheeler, S.M. \& Beatly, T. (2009). The sustainable urban development reader (2nd ed.). Routledge.

Wietske, M. \& Jeffrey, P. (2005). IWRM and adaptive management: Synergy or conflict? WB 1 Transition to AM of River Basins; Status NeWater.

Wong, T.H.F. (2006). An overview of water sensitive urban design practices in Australia: Ecological engineering. Water Practice \& Technology, 1(1). Prahran, Victoria, Australia: IWA Publishing. doi: 10.2166/WPT.2006018 